\title{
Toksisitas moluskisida fentin asetat terhadap hematologi dan pertumbuhan ikan nila, Oreochromiss niloticus (Linnaeus, 1758)
}

[Toxicity of fentin acetate molluscicide on haematological and growth of Nile tilapia, Oreochromis niloticus (Linnaeus, 1758)]

\author{
${ }^{1}$ Aisyah Lukmini ${ }^{\rtimes},{ }^{2}$ Eddy Supriyono, ${ }^{2}$ Tatag Budiardi \\ ${ }^{1}$ Sekolah Pascasarjana, Fakultas Perikanan dan Ilmu Kelautan, Institut Pertanian Bogor \\ ${ }^{2}$ Departemen Budidaya Perairan, Fakultas Perikanan dan Ilmu Kelautan, Institut Pertanian Bogor \\ Kampus IPB Darmaga Bogor 16680
}

Diterima: 26 Januari 2016; Disetujui: 29 November 2016

\begin{abstract}
Abstrak
Fentin asetat $\left(\mathrm{C}_{20} \mathrm{H}_{18} \mathrm{O}_{2} \mathrm{Sn}\right)$ digunakan sebagai pestisida di sawah secara intensif untuk mematikan keong mas (Pomacea sp.). Tujuan penelitian ini adalah untuk menentukan pengaruh toksisitas subletal moluskisida fentin asetat terhadap karakteristik hematologi (eritrosit, hemoglobin, hematokrit, dan leukosit) dan pertumbuhan yuwana ikan nila (Oreochromis niloticus). Penelitian dilaksanakan pada bulan Mei sampai Juli 2015 di Laboratorium Lingkungan Departemen Akuakultur, Institut Pertanian Bogor. Penelitian ini menggunakan 12 akuarium berukuran 100x50x50 $\mathrm{cm}^{3}$. Ikan nila

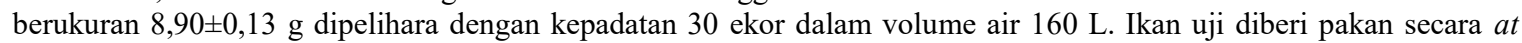
satiation serta dilakukan penggantian air setiap 24 jam dengan konsentrasi bahan uji yang sama. Rancangan penelitian yang digunakan adalah rancangan acak lengkap dengan empat perlakuan dan tiga ulangan dengan konsentrasi fentin asetat, yaitu: 0,00 (kontrol); 0,003; 0,008; dan 0,015 mg. $\mathrm{L}^{-1}$ selama 21 hari. Analisis terhadap karakteristik hematologi dan pertumbuhan ikan nila menggunakan anova. Konsentrasi sublethal moluskisida fentin asetat berpengaruh nyata terhadap penurunan karakteristik hematologi dan pertumbuhan ikan nila.
\end{abstract}

Kata penting: hematologi, Oreochromis niloticus, fentin asetat, pertumbuhan, sublethal

\begin{abstract}
Fentin acetate $\left(\mathrm{C}_{20} \mathrm{H}_{18} \mathrm{O}_{2} \mathrm{Sn}\right)$ as pesticide is extensively used for killing golden apple snail (Pomacea sp.) in paddy field. This study was aimed to determine effect of sublethal molluscicide fentin acetate toxicity on the haematological characteristics (erythrocyte, hemoglobin, hematocrit, and leucocyte) and growth of juvenile Oreochromis niloticus. This research was conducted from May to July 2015 in Environment Laboratory of Aquaculture Department, Bogor Agricultural University. The research used twelve glass aquariums of $100 \times 50 \times 50 \mathrm{~cm}^{3}$ filled with $160 \mathrm{~L}$ water and put 30 juveniles per aquarium. Fish were fed at satiation during the treatment and water exchange for every 24 hour. Research design was complete experimental randomized with four treatments and three replications of different fentin acetate concentrations i.e. $0.00 ; 0.003 ; 0.008 ; 0.015 \mathrm{mg} \mathrm{L}^{-1}$ for 21 days. The haematological characteristics and growth of fish were compared with ANOVA. The result indicates that sublethal concentration of $0.003 \mathrm{mg} . \mathrm{L}^{-1}$ fentin acetate was significantly $(\mathrm{p}<0.05)$ decrease the haematological characteristics and growth of tilapia.
\end{abstract}

Keywords: haematology, Oreochromis niloticus, fentin acetat, growth, sublethal

\section{Pendahuluan}

Pencemaran air saat ini sudah menjadi masalah global. Salah satu bahan yang diketahui menyebabkan pencemaran air adalah pestisida. Salah satu pestisida yang diketahui bersifat toksik terhadap organisme akuatik adalah fentin asetat dengan nama kimia trifeniltin asetat (berdasarkan International Union Pure and Applied Chemistry atau IUPAC). Fentin asetat merupakan senyawa organotin yang banyak digunakan sebagai pestisida dalam bidang pertanian (Watermann

$\triangle$ Penulis korespondensi

Alamat surel: aisyahlukmini46@gmail.com et al. 2008). Senyawa organotin adalah senyawa organometalik yang disusun oleh satu atau lebih ikatan stannum-karbon (Sn-C).

Penggunaan senyawa organotin sudah dilarang di beberapa negara di Eropa dan Amerika, sedangkan di beberapa negara di Asia, seperti Indonesia, Malaysia, dan India penggunaannya masih diizinkan. Di Indonesia, senyawa ini digunakan untuk mengendalikan siput murbei (Pomacea canaliculata Lamarck) di padi sawah, siput trisipan (Cheritidea sp.) di tambak udang windu 
dan bandeng, dan siput Parmarion pupilaris di tanaman kubis bunga (Ditjen PSP 2014). Menurut Cima et al. (1996), fentin asetat dengan dosis 0,6-1,2 $\mathrm{kg} \mathrm{ha}^{-1}$ merupakan moluskisida yang paling efektif untuk mengendalikan populasi siput murbei di sawah.

Senyawa organotin memiliki toksisitas yang sangat tinggi terhadap organisme akuatik. Senyawa ini bersifat lipofilik atau mudah larut dalam lemak yang dapat terserap dan terakumulasi di dalam tubuh organisme sehingga merupakan masalah dalam kegiatan budi daya (Cima et al. 1996). Dua jenis senyawa organotin yang diketahui bersifat sangat toksik bagi organisme akuatik adalah tributiltin dan trifeniltin. Beberapa hasil penelitian menunjukkan bahwa kedua senyawa ini mampu mengganggu pertumbuhan dan menurunkan tingkat kelangsungan hidup Mytilus edulis (Haggera et al. 2005), mampu menurunkan frekuensi pemijahan, kualitas telur, dan perkembangan gonad medaka (Oryzias latipes) (Zhang et al. 2008), dan mampu menghambat pertumbuhan dan respon enzim antioksidan pada mikroalga hijau (Scenedesmus quadricauda) (Xu et al. 2011).

Kannan \& Lee (1996) melaporkan bahwa tripheniltin (TPT) yang digunakan sebagai pestisida dan kemudian lepas ke perairan akan menumpuk di sedimen. Hasil penelitian Harino et al. (2012) di tiga lokasi perairan di Indonesia yaitu Bitung, Manado, dan Teluk Jakarta menemukan bahwa sedimen di tiga lokasi tersebut mengandung tributiltin dan tripheniltin dengan konsentrasi yang sangat tinggi. Konsentrasi senyawa tributiltin yang terdeteksi di tiga lokasi tersebut masing- masing berkisar antara 160-350 $\mu \mathrm{g} \mathrm{kg}^{-1}$ berat kering (Bitung), $89 \mu \mathrm{g} \mathrm{kg}^{-1}$ (Manado), dan 0,4-52 $\mu \mathrm{g} \mathrm{kg}^{-1}$ (teluk Jakarta). Senyawa tripheniltin (TPT) yang ditemukan di Bitung, Manado, dan teluk Jakarta masing-masing berki- sar antara $<0,1-19 \mu \mathrm{g} \mathrm{kg}^{-1}, 0,1 \mu \mathrm{g} \mathrm{kg}^{-1}$, dan $<0,1$ $-7,1 \mu \mathrm{g} \mathrm{kg}^{-1}$.

Tingginya kandungan fentin asetat baik di sedimen maupun di perairan, akan membahayakan organisme akuatik yang hidup di dalamnya. Hal ini diperparah dengan fakta bahwa air sungai dan waduk sering dimanfaatkan sebagai sumber air pasok budi daya ikan, sehingga akan mengancam kegiatan budi daya ikan yang sedang giat dikembangkan oleh masyarakat Indonesia, misalnya ikan nila (Oreochromis niloticus). Komoditas ini dibudidayakan dengan memanfaatkan air sungai dan waduk sebagai sumber air pasok sehingga sangat berpotensi terpapar fentin asetat yang ada di air.

Ikan yang terpapar bahan pencemar, akan mengalami perubahan pada karakteristik hematologinya. Penelitian Saravanan et al. (2011) menunjukkan adanya penurunan jumlah sel darah merah, konsentrasi hemoglobin, dan konsentrasi hematokrit pada ikan mas (Cyprinus carpio) yang dipapar insektisida organoklorin lindan. Penelitian Nirmala et al. (2012) menunjukkan adanya penurunan jumlah sel darah merah, hemoglobin, dan hematokrit pada ikan nila (Oreochromis niloticus) yang dipapar logam berat merkuri (Hg).

Penelitian ini bertujuan untuk menganalisis dampak pemaparan fentin asetat dengan konsentrasi berbeda terhadap karakteristik hematologi yang meliputi eritrosit, hemoglobin, hematokrit, dan leukosit pada ikan nila Oreochromis niloticus. Selain itu juga dilakukan pengamatan terhadap laju pertumbuhannya.

\section{Bahan dan metode}

Penelitian dilaksanakan pada bulan Mei hingga Juli 2015 di Laboratorium Lingkungan dan Laboratorium Kesehatan Ikan Departemen Budidaya Perairan, Fakultas Perikanan dan Ilmu 
Kelautan, Institut Pertanian Bogor, Bogor. Wadah uji yang digunakan adalah akuarium ukuran 100x50x50 $\mathrm{cm}^{3}$ sebanyak 12 buah. Bahan yang digunakan untuk penelitian ini adalah fentin asetat $\left(\mathrm{C}_{20} \mathrm{H}_{18} \mathrm{O}_{2} \mathrm{Sn}\right)$ dalam bentuk serbuk.

Biota uji yang digunakan adalah ikan nila

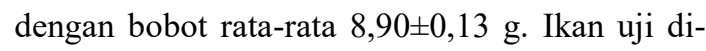
masukkan pada tiap akuarium perlakuan yang bervolume $160 \mathrm{~L}$ dan padat tebar 30 ekor per akuarium. Ikan tersebut dipelihara selama 21 hari dengan pemberian pakan berupa pelet secara $a d$ satiation. Kualitas air media pemeliharaan dipertahankan dengan mengganti air sebanyak 50\% dari volume air total tiap harinya dengan air stok yang mengandung konsentrasi fentin asetat yang sesuai dengan masing-masing perlakuan.

Rancangan yang digunakan dalam penelitian ini adalah rancangan acak lengkap, dengan empat perlakuan dan tiga ulangan, yaitu kontrol (tanpa fentin asetat atau $0 \mathrm{ppm}$ ), A (fentin asetat $0,003 \mathrm{ppm}$ ), B (fentin asetat 0,008 ppm), dan C (fentin asetat 0,015 ppm). Penentuan konsentrasi didasarkan pada hasil uji akut $\left(\mathrm{LC}_{50}\right)$ selama 96 jam.

Penimbangan bobot ikan uji untuk menghitung laju pertumbuhan spesifik dilakukan pada setiap unit percobaan pada awal dan akhir penelitian. Sampling gambaran darah dilakukan setiap tujuh hari, yaitu pada hari ke-0, 7, 14, dan 21 . Sebelum diambil darahnya, ikan dibius terlebih dahulu menggunakan MS222, kemudian darah diambil dari bagian ekor sebanyak $0,6 \mathrm{ml}$ dari dua ekor ikan menggunakan syringe steril berukuran $1 \mathrm{ml}$ yang sebelumnya dicuci dengan antikoagulan (Na sitrat 3,8\%). Sampel darah digunakan untuk pengukuran total eritrosit (TE), kadar hemoglobin $(\mathrm{Hb})$, kadar hematokrit $(\mathrm{Hc})$ dan total leukosit (TL).

Pengukuran TE diawali dengan pengambilan sampel darah menggunakan pipet yang ber- isi bulir bewarna merah sampai skala 1, kemudian ditambahkan larutan Hayem's sampai skala 101, lalu dilakukan pengadukan dengan menggoyangkan pipet yang sama selama 3-5 menit hingga darah dan larutan Hayem's tercampur rata. Tetesan pertama dibuang dan tetesan berikutnya diteteskan pada hemasitometer, kemudian ditutup dengan gelas penutup dan diamati dengan mikroskop pembesaran 400x. Penghitungan TE dilakukan pada lima kotak kecil dalam hemasitometer dengan persamaan sebagai berikut:

\section{$\mathrm{TE}=\Sigma$ eritrosit $\mathrm{x} 1 /($ volume kotak $) \times$ faktor pengenceran}

Prosedur pengukuran kadar $\mathrm{Hb}$ adalah sebagai berikut. Sampel darah dihisap menggunakan pipet Sahli hingga skala $20 \mathrm{~mm}^{3}$ atau $0,2 \mathrm{ml}$, kemudian dimasukkan ke dalam tabung Hb-meter yang telah diisi dengan $\mathrm{HCl} 0,1 \mathrm{~N}$ sampai skala 10 (merah), lalu dilakukan pengadukan dan didiamkan selama 3-5 menit. Selanjutnya, akuades dimasukkan ke dalam tabung Hb-meter hingga terjadi perubahan warna seperti warna larutan standar pada Hb-meter. Skala dibaca dengan melihat permukaan cairan dan dicocokkan dengan skala tabung Sahli yang dilihat pada skala jalur g\% (kuning) yang berarti banyaknya Hb per 100 $\mathrm{ml}$ darah.

Kadar Hc diukur dengan mengambil sampel darah menggunakan tabung mikrohematokrit dan disentrifus dengan kecepatan 5000 rpm selama 5 menit. Kadar hematokrit diketahui dengan membandingkan panjang sel darah yang mengendap dengan panjang total volume darah pada tabung mikrohematokrit

\section{Hematokrit $=($ volume sel darah merah $) /($ total} volume darah) x 100

Prosedur pengukuran TL adalah sebagai berikut. Sampel darah diambil menggunakan pipet yang berisi bulir bewarna putih sampai skala 0,5, kemudian ditambahkan larutan Turk's sampai skala 11 , lalu dilakukan pengadukan dengan 
menggoyangkan pipet selama 3-5 menit hingga darah dan larutan Turk's tercampur rata. Tetesan pertama dibuang dan tetesan berikutnya diteteskan pada hemasitometer, kemudian ditutup dengan gelas penutup dan diamati di bawah mikroskop dengan pembesaran 400x. Penghitungan TL dilakukan pada empat kotak besar dalam hemasitometer menggunakan persamaan sebagai berikut:

\section{$\mathrm{TL}=\Sigma$ leukosit $\times 1 /($ volume kotak $) \times$ faktor pengenceran}

Pengukuran laju pertumbuhan spesifik menggunakan persamaan (Giri et al. 2013) sebagai berikut:

\section{$\mathrm{LPS}=100 \times(\ln \mathrm{We}-\ln \mathrm{Ws}) / \mathrm{t}$}

Keterangan: LPS= laju pertumbuhan spesifik (\%), $\mathrm{We}=$ rata-rata bobot ikan pada akhir penelitian $(\mathrm{g})$, $\mathrm{Ws}=$ rata-rata bobot ikan pada awal penelitian $(\mathrm{g}), \mathrm{t}=$ waktu pemeliharaan (hari)

Data yang telah diperoleh kemudian ditabulasi dan dianalisis menggunakan Microsoft Excel dan SPSS 17. Analisis ragam (ANOVA) dengan uji F pada selang kepercayaan 95\% digunakan untuk menentukan pengaruh perlakuan terhadap perubahan karakteristik hematologi dan pertumbuhan. Apabila berpengaruh nyata, maka dilanjutkan dengan uji Duncan.

\section{Hasil}

Karakteristik hematologi

$\underline{\text { Total eritrosit }}$

Total eritrosit pada perlakuan A $(0,003$ ppm), B (0,008 ppm), dan C (0,015 ppm) cenderung mengalami penurunan dari awal sampai akhir penelitian (Gambar 1). Uji statistik menunjukkan kontrol berbeda nyata $(p<0,05)$ dengan ketiga perlakuan. Rata-rata total eritrosit pada awal penelitian adalah $1,80 \times 10^{6} \mathrm{sel} \mathrm{m^{-3 }}$. Pada hari ketujuh total eritrosit tertinggi terlihat pada perlakuan kontrol $\left(1,83 \times 10^{6} \mathrm{sel} \mathrm{mm}^{-3}\right)$ sedangkan yang terendah pada perlakuan $C\left(0,57 \times 10^{6}\right.$ sel $\mathrm{mm}^{-3}$ ). Pada hari ke-14 total eritrosit tertinggi masih pada kontrol $\left(1,89 \times 10^{6} \mathrm{sel} \mathrm{mm}^{-3}\right)$ diikuti perlakuan A $\left(0,88 \times 10^{6} \mathrm{sel} \mathrm{mm}^{-3}\right)$, dan B $(0,73 \times$ $10^{6} \mathrm{sel} \mathrm{mm}^{-3}$ ). Sementara pada hari ke-21, jumlah eritrosit pada perlakuan kontrol sebesar 1,90 x

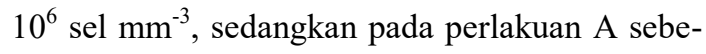
sar $0,82 \times 10^{6} \mathrm{sel} \mathrm{mm}^{-3}$, dan total eritrosit terendah pada perlakuan B yaitu $0,56 \times 10^{6} \mathrm{sel} \mathrm{mm}^{-3}$. Dari hari ke-14 sampai akhir penelitian, tidak diperoleh data total eritrosit pada perlakuan $\mathrm{C}$ disebabkan semua ikan perlakuan pada konsentrasi ini mengalami kematian setelah hari ketujuh penelitian.

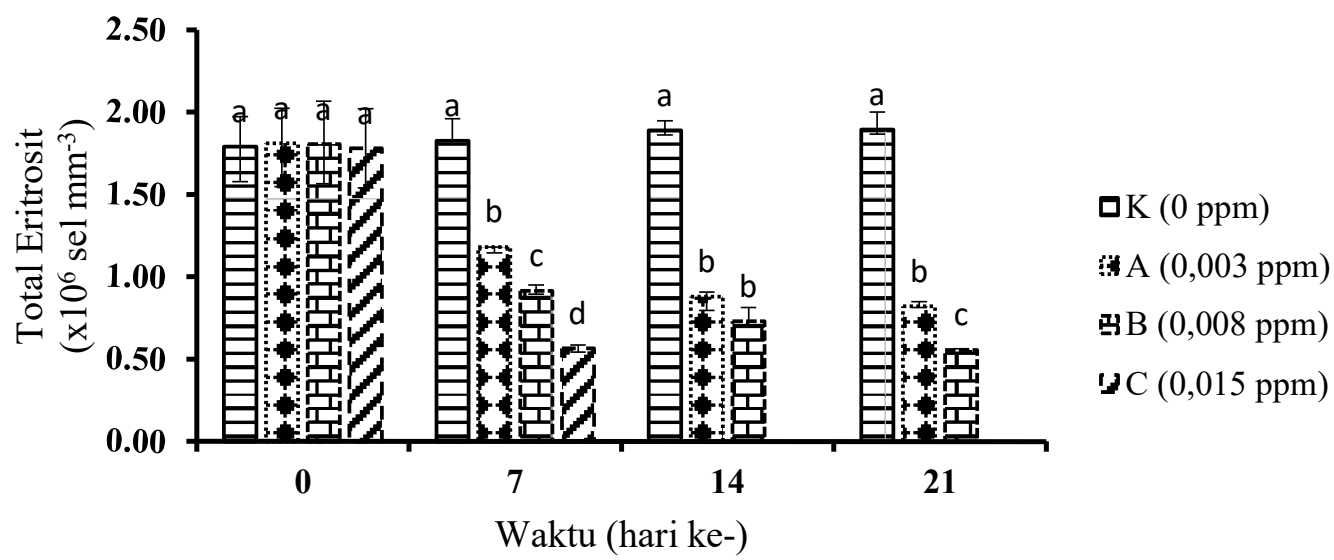

Gambar 1. Jumlah eritrosit $\left(\times 10^{6} \mathrm{sel} / \mathrm{mm}^{3}\right)$ ikan nila selama penelitian. Huruf tika atas yang berbeda pada hari yang sama menunjukkan perbedaan nyata $(\mathrm{p}<0,05)$ 


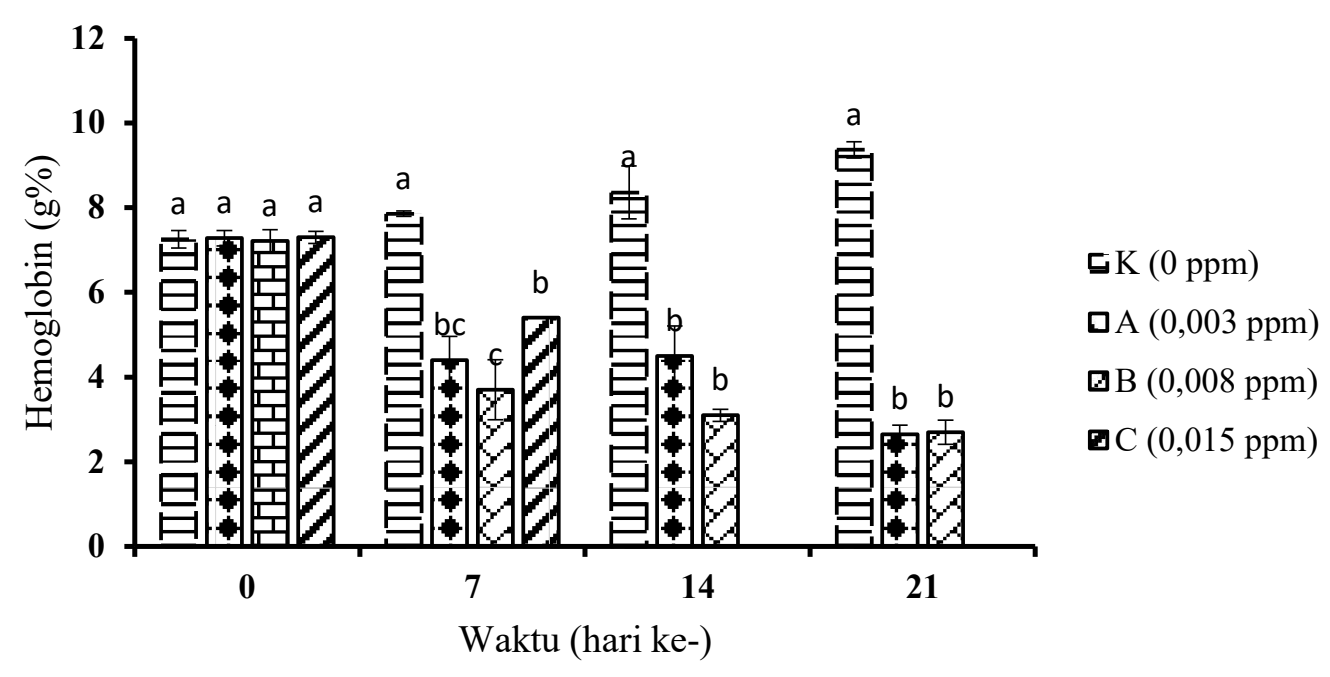

Gambar 2. Kadar hemoglobin (g\%) ikan nila selama penelitian. Huruf tika atas yang berbeda pada hari yang sama menunjukkan perbedaan nyata $(\mathrm{p}<0,05)$

\section{$\underline{\text { Hemoglobin }}$}

Selama penelitian, nilai hemoglobin pada perlakuan A, B, dan $\mathrm{C}$ menunjukkan kecenderungan menurun (Gambar 2). Rata-rata kadar hemoglobin pada awal penelitian adalah 7,26 g\%. Pada hari ketujuh, nilai hemoglobin tertinggi terdapat pada perlakuan $\mathrm{K}(0 \mathrm{ppm})$ sebesar $7,8 \mathrm{~g} \%$, dan berbeda nyata $(\mathrm{p}<0,05)$ dengan perlakuan $\mathrm{A}$ (0,003 ppm) yang sebesar 4,4 g\%, B (0,008 ppm) yang sebesar $3,7 \mathrm{~g} \%$, dan $\mathrm{C}(0,015 \mathrm{ppm})$ yang sebesar 5,4 g\%. Pada hari ke-14 kontrol $(8,36 \mathrm{~g} \%)$ berbeda nyata $(\mathrm{p}<0,05)$ dengan perlakuan A (4,5 g\%) dan B (3,1 g\%). Demikian juga pada pengamatan hari ke-21, perlakuan A $(2,65$ $\mathrm{g} \%)$ dan B (2,7 g\%) menunjukkan beda nyata $(\mathrm{p}<0,05)$ terhadap kontrol $(9,365 \mathrm{~g} \%)$.

\section{$\underline{\text { Hematokrit }}$}

Pada Gambar 3 terlihat bahwa selama penelitian terjadi kecenderungan penurunan nilai hematokrit ikan uji. Rata-rata kadar hematokrit pada awal penelitian adalah 27,79\%. Pada pengamatan hari ketujuh, nilai hematokrit tertinggi ada pada kontrol (30\%) sedangkan yang terendah pada perlakuan B $(12,68 \%)$. Pada pengamatan hari ke-14, kontrol berbeda nyata $(\mathrm{p}<0,05)$ terhadap perlakuan A dan B. Nilai hematokrit perlakuan kontrol, A, dan B masing-masing sebesar $31,83 \%$, 18,53\%, dan $12,34 \%$. Pada pengamatan hari ke-21 kadar hematokrit pada kontrol $(32,27 \%)$ berbeda nyata $(\mathrm{p}<0,05)$ dengan perlakuan A $(12,75 \%)$ dan B (5,85\%).

\section{$\underline{\text { Leukosit }}$}

Total leukosit ikan nila pada perlakuan A, $\mathrm{B}$, dan $\mathrm{C}$ cenderung terus meningkat hingga akhir penelitian (Gambar 4). Rata-rata total leukosit pada awal penelitian adalah $7,10 \times 10^{4} \mathrm{sel} \mathrm{mm}^{-3}$. Pada hari ketujuh, total leukosit terendah ada pada kontrol $\left(7,52 \times 10^{4} \mathrm{sel} \mathrm{mm}^{-3}\right)$ sedangkan yang tertinggi pada perlakuan $\mathrm{C}\left(8,81 \times 10^{4} \mathrm{sel} \mathrm{mm}^{-3}\right)$. Pada pengamatan hari ke-14, kontrol $\left(7,49 \times 10^{4}\right.$ sel $\left.\mathrm{mm}^{-3}\right)$ menunjukkan beda nyata $(\mathrm{p}<0,05)$ terhadap perlakuan $\mathrm{A}\left(8,42 \times 10^{4} \mathrm{sel} \mathrm{mm}^{-3}\right)$ dan $\mathrm{B}$

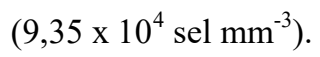




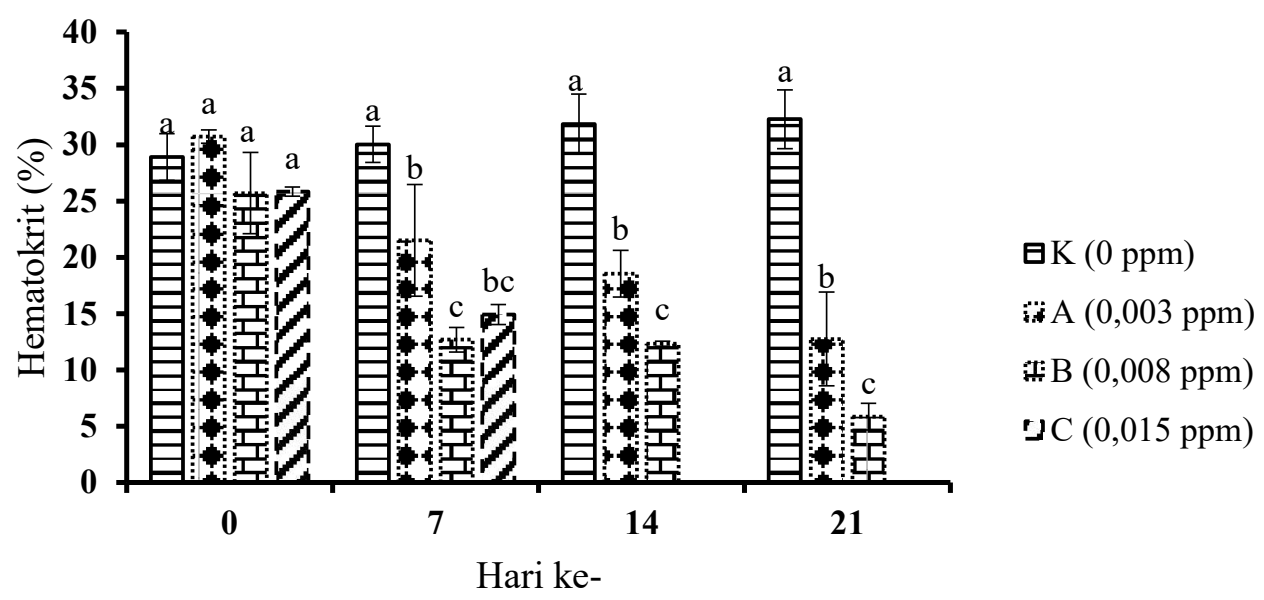

Gambar 3. Kadar hematokrit (\%) ikan nila (Oreochromis sp.) selama penelitian. Huruf tika atas yang berbeda pada hari yang sama menunjukkan perbedaan nyata $(\mathrm{p}<0,05)$

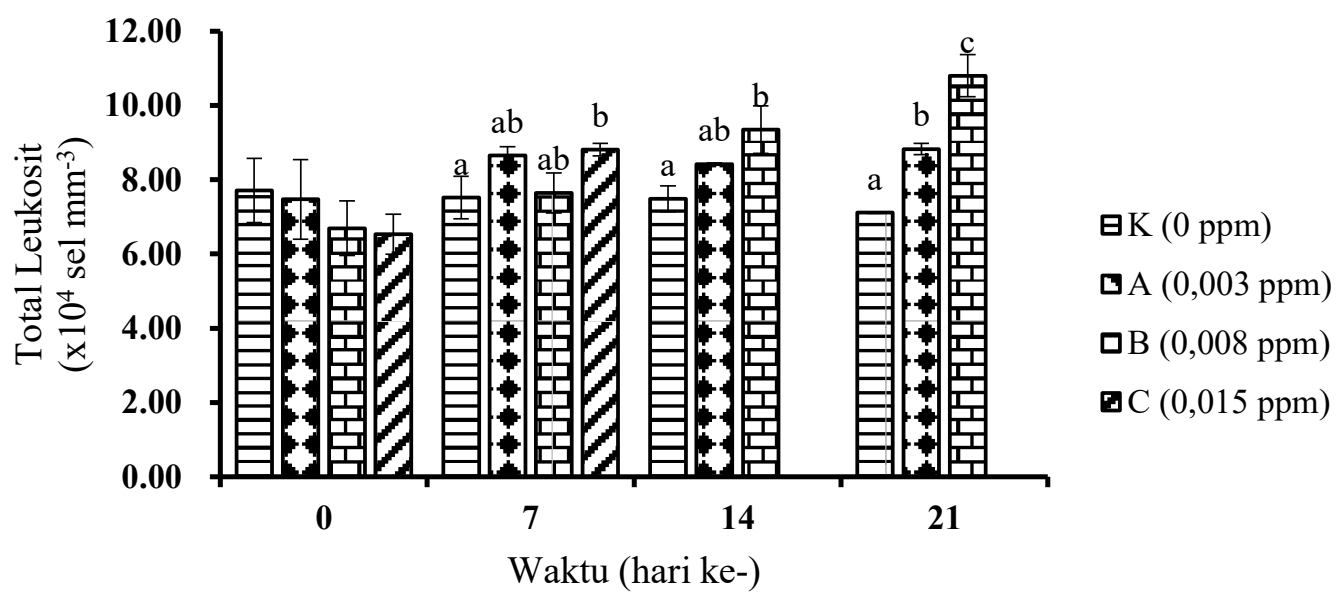

Gambar 4. Jumlah leukosit $\left(\times 10^{5} \mathrm{sel} \mathrm{mm}^{-3}\right)$ ikan nila selama penelitian. Huruf tika atas yang berbeda pada hari yang sama menunjukkan perbedaan nyata $(\mathrm{p}<0,05)$

Tabel 1 Laju pertumbuhan spesifik pada akhir penelitian

\begin{tabular}{cc}
\hline Konsentrasi fentin asetat $(\mathrm{ppm})$ & LPS $(\%)$ \\
\hline $0(\mathrm{~K})$ & $1,03 \pm 1,13^{\mathrm{a}}$ \\
$0,003(\mathrm{~A})$ & $0,08 \pm 0,17^{\mathrm{a}}$ \\
$0,008(\mathrm{~B})$ & $-1,70 \pm 0,96^{\mathrm{b}}$ \\
$0,015(\mathrm{C})$ & - \\
\hline
\end{tabular}

* huruf tika atas yang berbeda menunjukkan perbedaan nyata $(\mathrm{p}<0,05)$

Laju pertumbuhan spesifik

Data laju pertumbuhan spesifik (LPS) pada akhir penelitian disajikan pada Tabel 1. Hasil penelitian ini menunjukkan bahwa perlakuan B memiliki laju pertumbuhan yang paling rendah yaitu $-1,70 \%$. Hasil analisis statistik menunjukkan bahwa perlakuan B berbeda nyata dengan kontrol $(\mathrm{p}<0,05)$. Pemberian fentin asetat dengan konsentrasi 0,008 ppm terbukti mampu menurunkan laju pertumbuhan spesifik juvenil ikan nila. 


\section{Pembahasan}

Parameter darah merupakan suatu indikator adanya perubahan kondisi kesehatan ikan, baik karena faktor infeksi (mikroorganisme) maupun karena faktor non infeksi oleh lingkungan, genetik, dan nutrisi. Hasil penelitian ini menunjukkan terjadinya penurunan total eritrosit, kadar hemoglobin, dan kadar hematokrit seiring dengan bertambahnya konsentrasi fentin asetat pada media pemeliharaan. Hasil pemeriksaan gambaran darah pada hari ke-7, ke-14 dan ke-21 menunjukkan adanya penurunan jumlah total eritrosit, kadar hemoglobin, dan kadar hematokrit pada semua perlakuan yang diberi penambahan fentin asetat. Menurut Da Cuna et al. (2011), perubahan kondisi hematologi yang meliputi penurunan total eritrosit, kadar hemoglobin, dan kadar hematokrit merupakan ciri anemia.

Anemia bisa disebabkan berkurangnya pelepasan eritrosit di dalam sirkulasi darah. Salah satu organ yang berperan dalam produksi eritrosit adalah ginjal. Ginjal merupakan organ hematogenik paling penting pada ikan. Ginjal bagian anterior adalah organ utama pembentuk darah pada teleostei. Terjadinya gangguan pada ginjal menyebabkan produksi darah juga terganggu yang selanjutnya menyebabkan penurunan terhadap produksi eritrosit. Hasil penelitian Lukas (2010) menunjukkan terjadinya mineralisasi, hemorage, dan edema pada ginjal ikan nila yang dipelihara pada media yang mengandung $0,3 \mathrm{mg} \mathrm{L}^{-1} \mathrm{Cu}$. Kerusakan ini diikuti dengan adanya penurunan total eritrosit, kadar hemoglobin, dan kadar hematokrit yang disebabkan kerusakan jaringan ginjal dan insang ikan akibat akumulasi $\mathrm{Cu}$. Benli \& Ozkul (2010) menemukan terjadinya perubahan histologi pada organ hati ikan nila yang dipapar insektisida fenitrothion selama 96 jam. Kerusakan tersebut berupa degenerasi hidrophyl (cloudy swelling), degenerasi hidropik, dan infiltrasi lemak, sedangkan di ginjal ditemukan adanya hiperemia dan hemorage.

Terjadinya anemia juga terkait dengan adanya gangguan dalam penyerapan zat besi (Fe). Senyawa organotin mampu menghambat sintesis $\mathrm{Hb}$ dengan cara mengganggu penyerapan zat besi (Fe) (Boyer 1989). Mineral Fe merupakan unsur esensial yang berperan dalam sintesis hemoglobin (Setiawati et al. 2007). Berkurangnya zat besi di dalam darah akan menyebabkan berkurangnya konsentrasi hemoglobin di dalam darah. Penurunan kadar hemoglobin menandakan bahwa kemampuan ikan untuk menyediakan oksigen yang cukup bagi jaringan tubuh mengalami keterbatasan sehingga terjadi penurunan aktivitas fisik (Wepener et al. 1992).

Hasil penelitian ini menunjukkan bahwa jumlah leukosit meningkat seiring dengan peningkatan konsentrasi fentin asetat pada media pemeliharaan (Gambar 4). Hal ini selaras dengan hasil penelitian Harabawy \& Ibrahim (2014) yang menunjukkan terjadinya peningkatan total leukosit secara signifikan pada ikan lele (Clarias gariepinus) yang dipapar pestisida carbofuran selama 35 hari. Peningkatan ini mungkin dikarenakan respon protektif dari tubuh ikan selama kondisi stres yang diakibatkan oleh paparan fentin asetat. Kenaikan leukosit mengindikasikan terjadinya kerusakan akibat infeksi jaringan tubuh, stres fisik yang parah, dan leukositosis. Leukositosis adalah keadaan dengan jumlah sel darah putih dalam darah meningkat melebihi nilai normal. Peningkatan leukosit juga bisa menjadi gambaran bahwa tubuh ikan mampu menghadapi stres dengan cara membentuk lebih banyak leukosit (Abhijith et al. 2012).

Hasil penelitian menunjukkan semakin tinggi konsentrasi fentin asetat, maka laju pertumbuhan ikan nila semakin rendah (Tabel 1). Laju pertumbuhan paling tinggi ada pada kontrol 
sedangkan yang terendah ada pada perlakuan B. Rendahnya laju pertumbuhan pada penelitian ini diduga karena menurunnya jumlah eritrosit dan hemoglobin (Gambar 1 dan 2). Hemoglobin berfungsi mengikat oksigen yang digunakan dalam proses katabolisme untuk menghasilkan energi. Kemampuan mengikat oksigen dalam darah bergantung kepada jumlah hemoglobin dalam sel darah merah. Kadar hemoglobin yang rendah pada perlakuan penambahan fentin asetat menyebabkan metabolisme menjadi terhambat dan energi yang dihasilkan menjadi sedikit. Hal ini berdampak pada pertumbuhan ikan menjadi rendah. Penurunan total eritrosit akan mengakibatkan suplai makanan ke sel, jaringan dan organ akan berkurang sehingga metabolisme akan terhambat (Bastami et al. 2009)

Penurunan laju pertumbuhan juga terjadi pada ikan yang dipaparkan dengan berbagai jenis pestisida. Ikan mas setelah dipaparkan moluskisida niklosamida pada konsentrasi sublethal 0,01 ; 0,03 dan 0,05 ppm selama 12 minggu memperlihatkan penurunan laju pertumbuhan spesifik pada semua perlakuan (Supriyono et al. 2013). Ikan nila yang dipapar dua jenis pestisida yaitu dimethoate (20, 10 dan $\left.5 \mathrm{mg} \mathrm{L}^{-1}\right)$ dan malathion (2,0; 1,0 dan $0,5 \mathrm{mg} \mathrm{L}^{-1}$ ) mengalami penurunan laju pertumbuhan dan perubahan kondisi hematologi berupa penurunan jumlah eritrosit, kadar hemoglobin, dan kadar hematokrit (Sweilum 2006).

\section{Simpulan}

Ikan nila yang dipapar moluskisida fentin asetat pada konsentrasi $\geq 0,008$ ppm menunjukkan penurunan laju pertumbuhan yang disebabkan oleh penurunan total eritrosit, kadar hemoglobin, kadar hematokrit, dan peningkatan total leukosit.

\section{Daftar pustaka}

Abhijith BD, Ramesh M, Poopal RK. 2012. Sublethal toxicological evaluation of methyl parathion on some haematological and biochemical parameters in an Indian major carp Catla catla. Comparative Clinical Pathology, 21(1): 55-61.

Bastami K, Darvish, Moradlou AH, Zaragabadi AM, Salehi MSV, Shakiba MM. 2009. Measurement of some haematological characteristics of the wild carp. Comparative Clinical Pathology, 18 (9): 321-323

Benli ACK, Özkul A. 2010. Acute toxicity and histopathological effects of sublethal fenitrothion on Nile tilapia, Oreochromis niloticus. Pesticide Biochemistry and Physiology, 97(1): 32-35.

Boyer I. 1989. Toxicity of dibutyltin, tributyltin and other organotin compounds to humans and to experimental animals. Toxicology, 55(3): 253-298

Cima F, Ballarin L, Bressa G, Martinucci G, Burighel P. 1996. Toxicity of organotin compounds on embryos of a marine invertebrate (Styela plicata; Tunicata). Ecotoxicology and Environmental Safety, 35(2): $174-182$.

Da Cuna RH ,Va'zquez GR, Piol MN, Guerrero NV, Maggese MC Lo Nostro FL. 2011. Assessment of the acute toxicity of the organochlorine pesticide endosulfan in Cichlasoma dimerus (Teleostei, Perciformes). Ecotoxicology and Environmental Safety, 74(4):1065-1073.

Direktorat Jenderal Prasarana dan Sarana Pertanian (Ditjen PSP). 2014. Pestisida pertanian dan kehutanan terdaftar 2014 [Internet]. [diunduh 24 Januari 2015]. Tersedia pada http://psp.pertanian.go.id/

Giri SS, Sukumaran V, Oviya M. 2013. Potential probiotic Lactobacillus plantarum VSG3 improves the growth, immunity, and disease resistance of tropical freshwater fish, Labeo rohita. Fish and Shellfish Immunology, 34(2): 660-666.

Haggera JA, Depledge MH, Galloway TS. 2005. Toxicity of tributyltin in the marine mollusk Mytilus edulis. Marine Pollution Bulletin, 51(8-12): 811-816.

Harabawy ASA, Ibrahim ATA. 2014. Sublethal toxicity of carbofuran pesticide on the African catfish Clarias gariepinus (Burchell,1822) : Hematological, biochemical and cytogenetic response. Ecotoxicology and Environmental Safety, 103: 61-67. 
Harino H, Arifin Z, Rumengan IFM, Arai T, Ohji M, Miyazaki N. 2012. Distribution of Antifouling Biocides and Perfluoroalkyl Compounds in Sediments From Selected Locations in Indonesian Coastal Waters. Archives of Environmental Contamination and Toxicology, 63(1): 13-21.

Kannan K, Lee RF. 1996. Triphenyltin and its degradation products in foliage and soils from sprayed pecan orchards and in fish from adjacent ponds. Environmental Toxicolology and Chemistry, 15(9): 14921499.

[KKP] Kementerian Kelautan dan Perikanan. 2014. Kelautan dan Perikanan dalam Angka 2014 [Internet]. [diunduh 24 Januari 2015]. http://sidatik.kkp.go.id.

Lukas. 2010. Toksisitas logam berat $\mathrm{Cu}$ pada berbagai $\mathrm{pH}$ terhadap konsumsi oksigen dan respon hematologi ikan nila gift (Oreochromis sp.). Tesis. Institut Pertanian Bogor. $63 \mathrm{hlm}$.

Nirmala K, Hastuti YP, Yuniar V. 2012. Toksisitas merkuri $(\mathrm{Hg})$ dan tingkat kelangsungan hidup, pertumbuhan, gambaran darah, dan kerusakan organ pada ikan nila Oreochromis niloticus. Jurnal Akuakultur Indonesia, 11(1): 34-48.

Saravanan M, Kumar KP, Ramesh M. 2011. Haematological and biochemical responses of freshwater teleost fish Cyprinus carpio (Actinopterygii: Cypriniformes) during acute and chronic sublethal exposure to lindane. Pesticide Biochemistry and Physiology, 100 (11): 206-211.

Setiawati M, Mokoginta I, Suprayudi MA, Manalu W. 2007. Pengaruh penambahan mineral Fe pada pakan ikan terhadap status ke- sehatan ikan kerapu bebek (Cromileptes altivelis). Jurnal Perikanan dan Kelautan, 12(1): 55-63.

Supriyono E, Yosmaniar, Nirmala K, Sukenda. 2013. Toksisitas moluskisida niklosamida terhadap pertumbuhan dan kondisi histopatologi juwana ikan mas (Cyprinus carpio). Jurnal Iktiologi Indonesia, 13(1): 77-84

Sweilum MA. 2006. Effect of sub-lethal toxicity of some pesticides on growth parameters, haematological properties and total production of Nile tilapia (Oreochromis niloticus L) and water quality of ponds. Aquaculture Research, 37(11): 1079-1089.

Watermann B, Grote K, Gnass K, Kolodzey H, Thomsen A, Appel KE, Carnevali DC, Oehlmann US. 2008. Histological alterations in ovaries of pubertal female rats induced by triphenyltin. Experimental and Toxicologic Pathology, 60(4-5):313-321.

Wepener W, van Vuren JHJ, du Preez HH. 1992. Effect of manganese and iron at neutral $\mathrm{pH}$ values on the haematology of the banded tilapia, Tilapia sparrmanii. Environmental Contamination and Toxicology, 49: 613-619.

Xu J, Li M, Mak NK, Chen F, Jiang Y. 2011. Triphenyltin induced growth inhibition and antioxidative responses in the green microalga Scenedesmus quadricauda. Ecotoxicology, 20(1): 73-80.

Zhang Z, Hu J, Zhen H, Wu X, Huang C. 2008. Reproductive Inhibition and Transgenerational Toxicity of Triphenyltin on Medaka (Oryzias latipes) at Environmentally Relevant Levels. Environmental Science \& Technology, 42(21): 8133-8139. 